\title{
The MSA: An Instrument for Measuring Motivation to Study Abroad
}

\author{
Philip H. Anderson \\ University of St Thomas \\ Leigh Lawton \\ University of St Thomas
}

\section{Introduction ${ }^{1}$}

While there is a growing body of research on study abroad programs, as Li, Olson, and Frieze (2013) observed, "Research on study abroad has primarily focused on the effects or outcomes of study abroad participation on the students involved in these programs... Very limited attention has been devoted to studying factors affecting students' intention and decision to study abroad” (p. 74). A variety of factors are likely to influence whether students choose to participate in a study abroad program, what program they select, and what benefits they realize from participation. If we hope to attract students to our programs and organize the programs to optimize the students' experience, it is imperative that we are aware of what these factors are and how they influence students' decisions. The focus of this paper is on the development of an instrument that accurately measures the key factors motivating a student's decision to study abroad.

\section{Literature Review}

It is becoming increasingly clear that a study abroad experience can confer a wide range of benefits on participants. In 2004, Kitsantas reported, "Several studies focusing on study abroad outcomes have provided evidence that study abroad programs enhance students' worldview (Carlson \& Widman, 1988), global perspective (McCabe, 1994), cross-cultural effectiveness (Kitsantas \& Meyers, 2001), interest in travel, art, foreign languages, history, and architecture (Carsello \& Creaser, 1976), and increase reflective thought, self-reliance, self-confidence and personal well-being (Kuh \& Kaufman, 1984)" (p. 441). Li, Olson, and Frieze (2013) list studies showing such positive outcomes as “...the development of cognitive skills (Maddux \& Galinsky, 2009), self-confidence (Milstein, 2005), intercultural awareness (Langley \& Breese, 2005), second language skills (Magnan \& Back, 2007) and long-term career impact (Franklin, 2010) in the student participants" (p. 74). In a pre-post study, Rexeisen, Anderson, Lawton, and Hubbard (2008) concluded, "Overall this study supports that proposition that study abroad programs have a positive short-term impact on intercultural development" (p. 17). In yet another pre-post study, Anderson and Lawton (2011) reported that "students in the [semester abroad] program showed greater gains in intercultural development than did their on-campus counterparts ... The study results provide convincing support for the proposition that participation in a semester-length study abroad experience yields a significant increase in the participants' intercultural development” (p. 97).

While we have mounting evidence of the power of study abroad experiences, we have

${ }^{1}$ The authors would like to acknowledge the support provided by the American Institute for Foreign Study, and Ann Hubbard (VP with AIFS) for their support in this research. 
considerably less information about factors related to the experience. Some research is available concerning students' desire or intention to study abroad and it seems likely that these same factors influence the choice of a destination for those students who choose to participate in a study abroad program. Naffziger, Bott, and Mueller (2010) found six factors that influenced students' decisions to study abroad: fear of the unknown, curricular issues, financial considerations, commitments, previous travel experience, and social obligations. Li, Olson, and Frieze (2013) found that personality factors such as students' achievement motivation, neophilia, migrant personality and desire to help can discriminate between high versus low desire to study abroad. Their study suggests "important predispositional factors within students that affect their intention [to study abroad]... Understanding student characteristics may assist educators in developing different types of programs and better promotional strategies to attract a wider variety of students to participate in study abroad programs. One application of our results is on offering study abroad programs that match with students' needs" (pp. 80-81).

We know that not all students profit equally from a study abroad experience (Vande Berg, Connor-Linton, \& Paige, 2009). They reported on the relationship between intercultural development and variables such as prior language study, prior study abroad experience, class composition, student housing, cultural similarity between home and host cultures, and time spent with host nationals versus other U.S. nationals. It is intuitively reasonable that the parameters of a program (e.g., the duration of the program, living arrangements, language of instruction, magnitude of cultural "distance" between the U.S. and host cultures, etc.) impact the learning that occurs.

While many of the factors relating to relevant program parameters are readily apparent (Engle \& Engle, 2003), it is important to understand how students' motivation for participating in a study abroad program mediates the magnitude of those gains. As the literature suggests (and as anyone who has led a study abroad program can attest), students have a myriad of reasons for traveling abroad. It seems likely that a student who participates in an effort to increase his or her understanding of the world will experience different outcomes from a student who participates because the legal drinking age is lower in the host country.

For research to advance on the moderating influence of student motivation, an instrument is needed to classify these motivations so that students can be sorted into appropriate categories. This paper describes the development of a paper and pencil instrument that classifies the principal motivations for students participating in study abroad programs.

\section{Literature on Student Motivation to Study Abroad Program}

The development of the Motivation to Study Abroad (MSA) instrument began with a review of the literature. A wide range of sources were consulted ranging from research studies to promotional pieces touting the benefits of study abroad experiences. There are many articles that encourage students to travel and these sources frequently list presumed benefits of the experience (e.g., see Gale Encyclopedia of Education; Powers, 2006; Vistawide; Study Abroad 360; Community Colleges for International Development; Go Abroad.com; StudyAbroad.com). However, published research on student motivation for taking part in study abroad programs is surprisingly sparse (Dwyer \& Peters, 2004; Kitsantas, 2004; Ruhter McMillan \& Opem, 2004; Sumka, 1999; Preston, 2012). 
Two studies have appeared whose aim was quite similar to ours. Sanchez, Fornerino, and Zhang (2006) compared the study abroad motivations of U.S., French, and Chinese students and Nyaupane, Paris, and Teye (2010) measured the motivations of U.S. students who participated in study abroad programs in the South Pacific and Europe. A comparison of the findings of these studies is covered in the discussion section of this paper.

\section{Developing the Motivation for Studying Abroad Instrument}

In addition to the literature sources, we also administered an open-ended instrument to two groups of students at a large, Midwestern, private university who had enrolled in study abroad programs asking why they had chosen to participate. The motivations identified through the literature search and open-ended data collections were used to develop a list of 53 statements that reflected a variety of reasons for studying abroad.

Next, these 53 statements were administered to 120 students enrolled in a variety of study abroad programs sponsored by the above university as well as by the American Institute for Foreign Study (AIFS). This was a very cursory examination using all data available at the time to get a broad look at the instrument. Students were asked to indicate on a five point scale, how important each questionnaire item was in their decision to study abroad. Exploratory factor analysis was conducted on the data. This preliminary round of analysis resulted in the elimination of 16 statements from the pool of items. The remaining set of 37 statements was then administered to a new group of 173 students enrolled in study abroad programs and a second round of exploratory factor analysis was performed on this set of data. The results of this analysis can be found in Appendix 1.

Four factors emerged from this second round of analysis and the number of items in the instrument was further reduced. The final instrument shown in Appendix 2 consists of 23 statements covering the following four dimensions: World Enlightenment, Personal Growth, Career Development, and Entertainment. Appendix 3 shows the rubric for scoring the instrument.

Table 1. MSA Dimensions

\begin{tabular}{|l|l|l|l|l|l|l|}
\hline & Number of items & $\mathrm{n}$ & Mean & Median & Standard deviation & Cronbach's alpha \\
\hline World Enlightenment & 7 & 173 & 4.41 & 4.57 & 0.62 & 0.91 \\
\hline Personal Growth & 6 & 173 & 4.20 & 4.33 & 0.72 & 0.86 \\
\hline Career Development & 5 & 173 & 3.64 & 3.80 & 0.96 & 0.89 \\
\hline Entertainment & 5 & 173 & 1.77 & 1.60 & 0.75 & 0.82 \\
\hline
\end{tabular}




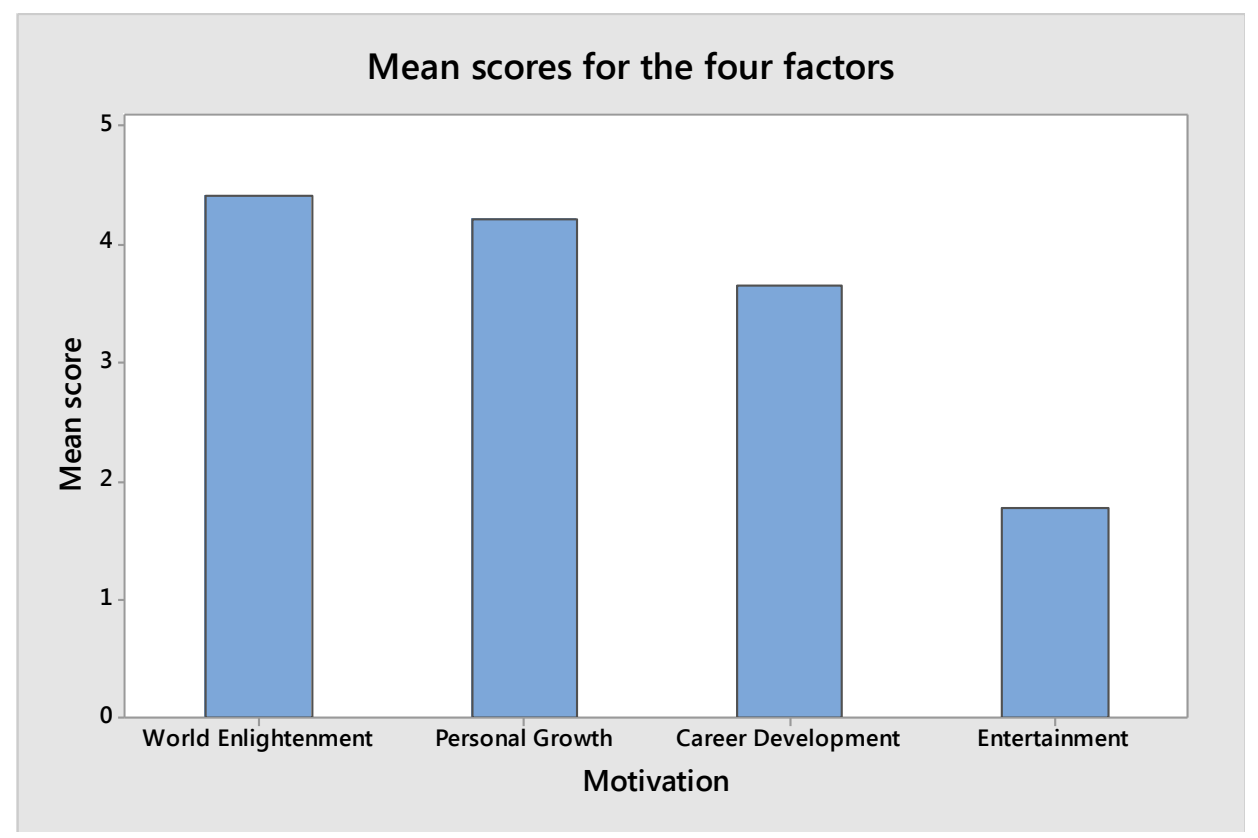

As can be seen in Table 1, World Enlightenment is the highest rated of the motivations for studying abroad followed by Personal Growth. Desire for Entertainment comes in a distant fourth. While this may be an encouraging finding for study abroad sponsors, it must be taken with a grain of salt. It is likely that students choosing to participate in a study abroad program may consciously or subconsciously be unwilling to admit their true reasons for choosing to participate. We address this potential self-report bias under Limitations, below.

The final stage in testing the adequacy of the Motivation to Study Abroad instrument was to subject this final pool of 23 statements to confirmatory factor analysis. For this analysis, a new set of 308 students who participated in AIFS international programs was used. The results of the confirmatory factor analysis support that this instrument provides an acceptable tool for measuring students' motivations for choosing to study abroad. The criteria for determining the quality of an instrument are shown in Table 2. "According to typical interpretation guidelines ..., values greater than .90 and .95 for the CFI and TLI are considered to be respectively indicative of adequate and excellent fit to the data, while values smaller than .08 or .06 for the RMSEA support respectively acceptable and excellent model fit" (Morin, Arens, \& Marsh, in press, p. 14). As can be seen from comparing the statistics for the MSA with these criteria, the MSA can be described as an adequate instrument for measuring motivation for studying abroad.

Table 2. Quality of Instrument Ratings

\begin{tabular}{|l|l|l|l|}
\hline & Excellent model & Adequate model & MSA statistics \\
\hline Comparative fit index (CFI) & $>0.95$ & $>0.90$ & 0.91 \\
\hline Tucker-Lewis Index (TLI) & $>0.95$ & $>0.90$ & 0.90 \\
\hline Root mean square error of approximation (RMSEA) & $<0.06$ & $<0.08$ & $\begin{array}{l}0.074 \\
90 \text { percent C.I. } 0.067 \text { to } 0.081\end{array}$ \\
\hline Standardized root mean square residual (SRMR) & $<0.06$ & $<0.08$ & 0.062 \\
\hline
\end{tabular}


Cronbach's alphas were computed for this new group of students, see Table 3. While the means and medians for two of the dimensions, World Enlightenment and Personal Growth, were a bit lower for this set of students than for the 173 students who were used at an earlier stage of model development (see Table 1), all of the remaining statistics were almost identical. The MSA instrument appears to produce consistent results and the reliability scores for the internal consistency of the four dimensions all are in the good to excellent range. These Cronbach alpha scores provide further evidence that the MSA instrument is a suitable tool for measuring student motivations.

Table 3. Cronbach Alphas

\begin{tabular}{|l|l|l|l|l|l|l|}
\hline & Number of items & $\mathrm{n}$ & Mean & Median & Standard deviation & Cronbach's alpha \\
\hline World Enlightenment & 7 & 308 & 4.23 & 4.36 & 0.68 & 0.91 \\
\hline Personal Growth & 6 & 308 & 4.05 & 4.20 & 0.68 & 0.86 \\
\hline Career Development & 5 & 308 & 3.63 & 3.80 & 0.97 & 0.90 \\
\hline Entertainment & 5 & 308 & 1.84 & 1.60 & 0.72 & 0.81 \\
\hline
\end{tabular}

\section{Limitations}

The motivation to study abroad instrument suffers from a problem common to many measurement tools relying on self-report. It is likely that social desirability leads to understating the importance of some motivations while overstating the importance of others. Even when students are assured that their responses are anonymous (as they were here), it is probable that they will overendorse motivations such as "Increase my understanding of the world" and underreport items such as "Do some serious partying."

While a self-reporting bias may well exist in the data, the patterns of student motivations can still provide insights for study abroad providers and universities offering study abroad programs. For example, even if students under-report their degree of desire for entertainment, thus yielding an artificially low average score on this dimension, relative scores still may yield useful information about which study abroad programs appeal to students with differing motivations. A second limitation of the present study is that data were collected exclusively from students participating in programs offered by U.S. institutions and virtually all study participants were from the U.S. Sanchez, Fornerino, and Zhang (2006) found that the motivation for participating in study abroad programs differed for students across different countries. Consequently, generalizing the results of the present study to other countries should be done with caution. While it is likely that most motivations for studying abroad transcend national boundaries, it is probable that some motivations are country specific.

\section{Discussion}

The aim of this study is rather limited. We are not presenting findings on how motivations differ by program or by country, nor are we describing how the outcomes of study abroad experiences are influenced by motivation. Rather we are providing an instrument to be used in future studies. As stated at the outset of this paper, it seems reasonable that the experiences and outcomes realized by students participating in study abroad experiences will be heavily influenced by their motivations for taking part in the program. While this hypothesis has intuitive appeal, it cannot be investigated without an instrument for assessing motivations. This study represents a rigorous effort to present such an instrument. Considerable care was devoted to generating a comprehensive set of potential motivations for participating in study abroad programs and considerable effort was put into testing and refining 
the instrument.

Since two previous studies have been published that describe the development of instruments to measure motivations, it is informative to compare the findings. Sanchez, Fornerino, and Zhang (2006) and Nyaupane, Paris, and Teye (2010) report studies that employed a similar methodology - factor analyzing a set of statements - to identify categories of motivations for participating in study abroad programs.

Sanchez, et al. (2006) generated a list of statements based on the open-ended responses of a sample of international students and students in China. Nyaupane, et al. (2010) used "thirty-five motivation questions...developed and modified from...previous studies" (p. 210). As with our study reported here, both of these studies had students respond to their motivations on five point scales.

A comparison of the findings for these three studies is shown in Table 4. Clear similarities exist across the three studies in terms of some of the dimensions. Based on an examination of the items, what we chose to label "World enlightenment" is very similar to Sanchez, et al.s (2006) "Search for new experience" and Nyaupane, et al.'s (2010) "International." This dimension covers increasing the student's understanding of the world and of other cultures (See Table 4A). The Sanchez, et al. (2006) and the Nyaupane, et al. (2010) studies also included more general items. We designated those items with an asterisk $\left(^{*}\right)$ in the tables. In our study, items similar to these (i.e., See things I've only known from pictures, Have an adventure, Have fun) loaded both on the Entertainment dimension as well as on the cultural/learning dimension. Consequently, we dropped these items from our instrument. While Sanchez, et al. (2006) do not provide their factor loadings, it's worth noting that in the Nyaupane, et al. (2010) study these two items had the lowest factor loadings (Visit several countries, 0.580 , and Travel outside of the U.S., 0.451). This dimension of world enlightenment appears to be cleanest when the items are limited to the cultural/learning dimensions.

Table 4A. Comparison of the findings of the three motivation studies

\begin{tabular}{|c|c|c|}
\hline Present Study & Sanchez, Fornerino, Zhang & Nyaupane, Paris, \& Teye \\
\hline $\begin{array}{l}\text { World enlightenment } \\
\text { Learn about the world } \\
\text { Better understand different } \\
\text { cultures } \\
\text { Interact with people from other } \\
\text { countries } \\
\text { Expand my world view } \\
\text { Enhance my understanding of } \\
\text { global affairs and events } \\
\text { Increase my understanding of the } \\
\text { world } \\
\text { Become acquainted with people } \\
\text { different from me }\end{array}$ & $\begin{array}{l}\text { Search for new experience } \\
\text { To experience another culture } \\
\text { To be exposed to people from other } \\
\text { countries } \\
\text { To live in another culture } \\
\text { To obtain a different view of the world } \\
\text { To have exciting experience } * \\
\text { To experience a lifestyle other than my own } \\
\text { To learn about other cultures } \\
\text { To travel } * \\
\text { To see the world * } \\
\text { To see new things } * \\
\text { To become part of a new culture } \\
\text { To have international experience } * \\
\text { To better learn about human civilization }\end{array}$ & $\begin{array}{l}\text { International } \\
\text { Socially/culturally learn more about } \\
\text { host country } \\
\text { Interact with people in host country } \\
\text { Experience culture of host country } \\
\text { Meet people from different country } \\
\text { Have an authentic experience with } \\
\text { past cultures } \\
\text { Get broader understanding of the } \\
\text { world } \\
\text { Visit several countries * } \\
\text { Travel outside of U.S. } \\
\text { Develop close relationships with } \\
\text { locals }\end{array}$ \\
\hline
\end{tabular}

This item had similar, low loadings (0.433 and 0.457) on two dimensions.

*Items denoted with asterisks, while related to World Enlightment, are more general in their focus. 
As shown in Table 4B, Sanchez, et al. (2006) and the present study identified a common dimension having to do with professional advancement. We labeled this dimension "Career development" while Sanchez, et al. (2006) labeled it "Improve a professional situation." An examination of the items in the two studies shows that several are very similar. However, Sanchez, et al. (2006) also included items in this dimension that are focused on the individual's children as opposed to career improvements that are personal in nature.

Table 4B. Comparison of the findings of the three motivation studies

\begin{tabular}{|l|l|l|}
\hline Present Study & Sanchez, Fornerino, Zhang & Nyaupane, Paris, \& Teye \\
\hline Career development & Improve a professional situation & \\
Gain career skills & To benefit my future career & \\
Prepare for my career & To make a professional work connection & \\
Gain in-depth knowledge in my & To more easily enter the job market & \\
chosen field & To find a work environment that allows me a & \\
Build my resume & chance to succeed & \\
& To learn about new ways of doing business & \\
& To help me be able to work in another country & \\
& To be richer & \\
& To be exposed to a higher academic level of & \\
& thought & \\
& To study at a prestigious university & \\
& To create my own independent life & \\
& To provide a good living to my children & \\
& So that my children can be exposed to a \\
& complete, modern and systematic educational & \\
& system & \\
\hline
\end{tabular}

While the similarities among the items are somewhat looser, the Sanchez, et al. (2006) and the present study share a dimension having to do with the entertainment value of the experience. We label the dimension "Entertainment" while Sanchez, et al. (2006) call it "Search for liberty/pleasure" (see Table 4C). Interestingly, Nyaupane, et al. (2010) did not have a similar dimension.

Table 4C. Comparison of the findings of the three motivation studies

\begin{tabular}{|l|l|l|}
\hline Present Study & Sanchez, Fornerino, Zhang & Nyaupane, Paris, \& Teye \\
\hline Entertainment & Search for liberty/pleasure & \\
Go out drinking & To Increase my enjoyment level & \\
Do some serious partying & To experience a more exotic life & \\
Make my friends a little envious of me & To have fun & \\
Experience the local nightlife (clubs, & To live independently without worrying & \\
bars, etc.) & so much about what others think of & \\
Have a romantic encounter & me & \\
& & \\
\hline
\end{tabular}

The remaining dimensions identified in the three studies appear to be reasonably unique. The present study has a set of items we chose to call "Personal growth." Surprisingly, neither of the other studies have any items that touch on this dimension. The closest would be what Sanchez, et al. (2006) labeled as "Learn other languages" (see Table 4D). But neither the Nyaupane, et al. (2010) study nor the present study included a dimension specifically having to do with learning a language. 
Table 4D. Comparison of the findings of the three motivation studies

\begin{tabular}{|l|l|l|}
\hline Present Study & Sanchez, Fornerino, Zhang & Nyaupane, Paris, \& Teye \\
\hline Personal growth & Learn other languages & \\
Learn to stand on my own two feet & To learn other languages & \\
Increase my self-confidence & To learn a beautiful language that I like & \\
Become more independent & very much & \\
Grow as a person & To learn a native language & \\
Gain maturity & & \\
Better understand myself & & \\
\hline
\end{tabular}

The Sanchez, et al. (2006) study included students from France and China as well as from the U.S. It appears that their added international dimension may have yielded a dimension that is more relevant to students from countries other than the U.S. Their dimension "Improve a social situation" included such items as "Because there are more opportunities in other countries than in my country to obtain a university degree", "To be able to freely practice my religious beliefs", and "To live where one's private life is respected", as well as items having to do with pleasing one's parents. Neither the present study nor the Nyaupane, et al. (2010) study included items intended to tap this facet of international travel.

Table 4E. Comparison of the findings of the three motivation studies

\begin{tabular}{|l|l|l|}
\hline Present Study & Sanchez, Fornerino, Zhang & Nyaupane, Paris, \& Teye \\
\hline & Improve a social situation & \\
& Because there are more opportunities in & \\
other countries than in my country to & & \\
& obtain a university degree & \\
& To improve my parents' social recognition & \\
& To please my parents & \\
& To live where personal relations are & \\
& relatively simple & \\
& To be able to freely practice my religious & \\
& beliefs & \\
& To live where one's private life is & \\
& respected & \\
\hline
\end{tabular}

Finally, the Nyaupane, et al. (2010) found two dimensions that were not identified in either the present study or the Sanchez, et al. (2006) study. While we included several items similar to Nyaupane, et al.'s (2010) "Escape" factor (i.e., Re-invent myself, Escape from the boredom of my routine, Escape from my personal problems) the loadings for these items split between "Entertainment" and "Personal growth" and failed to form a unique dimension. For Nyaupane, et al. (2010), the final factor, "Social," appears to be a combination of academic credit (Earn six academic credits and Earn academic credit while traveling), friendship (Travel with friends and Show friends/family that have been to host country), and entertainment (Buy goods and gifts from host country). In our study, we included several items dealing with friends and family as well as academics (Learn about historical events, Take electives not available at home, Learn about religions of the world, and Fulfill a graduation requirement), but none of these items yielded a separate, unique factor. 
Table 4F. Comparison of the findings of the three motivation studies

\begin{tabular}{|l|l|l|}
\hline Present Study & Sanchez, Fornerino, Zhang & Nyaupane, Paris, \& Teye \\
\hline & & Social \\
& & $\begin{array}{l}\text { Earn six academic credits } \\
\text { Earn academic credit while traveling } \\
\text { Show friends/family that have been to host } \\
\text { country } \\
\text { Travel with friends } \\
\end{array}$ \\
& & Buy goods and gifts from host country \\
\hline & $\begin{array}{l}\text { Escape } \\
\text { Get away from stressful situation } \\
\text { Escape social boundaries } \\
\text { Travel independently without family } \\
\text { Escape day-to-day life } \\
\text { Have convenience of prearranged travel } \\
\text { Escape legal boundaries } \\
\text { Develop close relationships with locals }\end{array}$ \\
\hline
\end{tabular}

This item had similar, low loadings (0.433 and 0.457$)$ on two dimensions.

\section{Conclusion}

The purpose of the present study is to provide researchers with an instrument for measuring student motivation for participating in a study abroad program. It seems likely that the study abroad destinations students select, the living arrangements they prefer, the activities they choose to engage in, and the benefits they derive from participating will be influenced by their motivation for traveling abroad. Without an instrument to categorize motivation, it is impossible to empirically test the impact of motivation on these program factors. The Motivation to Study Abroad (MSA) instrument presented here has face validity, has high statistical reliability, meets accepted criteria for reliability, and can be administered easily.

We hope that researchers will choose to administer and report the scores for the MSA and how they relate to intercultural development. Comparing the outcomes for various programs should help to shed light on some of the following questions:

Do students with different MSA profiles...

- choose different program destinations?

- choose programs of different duration?

- choose different housing arrangements (for example, home-stay, residence hall/dormitory, apartment)?

- choose different types of programs (e.g., island programs vs. direct enrollment)

- choose different course options while overseas?

- choose to spend their out-of-class time with different people (for example, classmates from the U.S. versus people from the host company)?

- participate in different types of extracurricular activities? 
Do the learning outcomes of students with different MSA profiles differ? (We might expect that the magnitude of the gains students achieve in cultural sensitivity and/or academics would vary for students with differing motivations.)

Do MSA profiles differ for students with differing degrees of international experience?

If those conducting research on study abroad programs report MSA scores along with information on the students' intercultural development and the characteristics of their programs (the destination of the program, the duration of the program, the housing arrangements, etc.), it is our hope that we can increase our understanding of the program characteristics that produce maximal gains for participating students.

\section{References}

Anderson, P. and Lawton, L. (Fall, 2011) Intercultural Development: Study Abroad vs. On-Campus Study. Frontiers: The Interdisciplinary Journal of Study Abroad, 21, 86-108.

Carlson, J.S., and Widaman, K.F. (1988). The effects of study abroad during college on attitudes toward other cultures. International Journal of Intercultural Relations. 12(1), 1-18.

Carsello, C., and Greaser, J. (1976). How college students change during study abroad. College Student Journal, 10, 276-278.

Community Colleges for International Development. Tips and benefits for your study abroad trip. Available at http://www.ccidinc.org/documents/Tips $\% 20$ and $\% 20$ benefits-Ecuador.pdf (accessed 8-7-09)

Dwyer, M. and Peters, C. (2004). The Benefits of Study Abroad: New Study Confirms Significant Gains. Transitions Abroad, available at http://www.transitionsabroad.com/publications/magazine/0403/benefits study abroad.shtml (accessed 8-4-14)

Engle, L. and Engle J. (2003). Study Abroad Levels: Toward a Classification of Program Types. Frontiers: The Interdisciplinary Journal of Study Abroad, 9, 1-20.

Franklin, K. (2010). Long-term career impact and professional applicability of the study abroad experience. Frontiers: The Interdisciplinary Journal of Study Abroad, 19, 169-190.

Gale Encyclopedia of Education. Study Abroad. Available at http://www.answers.com/topic/studyabroad (accessed 8-4-14)

Go Abroad.com. The Study Abroad Guide. Available at http://www.studyabroaddirectory.com/study-articles.cfm (accessed 8-4-14)

Kitsantas, A. (2004). Studying Abroad: The Role of College Students' Goals on the Development of Cross-Cultural Skills and Global Understanding. College Student Journal, 38(3), 441-452.

Kitsantas, A., \& Meyers, J. (2001). Studying Abroad: Does it enhance college student crosscultural awareness? Educational Resources Information Center, ED 456-648. ERIC paper presented at the combined annual meeting, San Diego State University and U.S. Department of Education Center for International Business Research.

Kuh, G.K., and Kauffman, N.F. (1984). The impact of study abroad on personal development of college students. Bloomington, IN: Indiana University School of Education. (ED 245 591).

Langley, C. S., \& Breese, J. R. (2005). Interacting sojourners: A study of students studying abroad. The Social Science Journal, 42, 313-321. 
Li, M., Olson, J. E., and Frieze, I. H. (2013). Students' Study Abroad Plans: the Influence of Motivational and Personality Factors. Frontiers: The Interdisciplinary Journal of Study Abroad, 23, 7389.

Maddux, W. W., and Galinsky, A. D. (2009). Cultural borders and mental barriers: The relationship between living abroad and creativity. Journal of Personality and Social Psychology, 96, 1047-1061.

Magnan, S. S., and Back, M. (2007). Social interaction and linguistic gain during study abroad. Foreign Language Annals, 40, 43-61.

McCabe, L.T. (1994). The development of a global perspective during participation in semester at sea: A comparative global education program. Educational Review, 46(3), 275-286.

Milstein, T. (2005). Transformation abroad: Sojourning and the perceived enhancement of selfefficacy. International Journal of Intercultural Relations, 29, 217-238.

Morin, A.J.S., Arens, A.K., and Marsh, H.W. (in press). A Bifactor Exploratory Structural Equation Modeling Framework for the Identification of Distinct Sources of Construct-Relevant Psychometric Multidimensionality. Structural Equation Modeling. Available at https://www.statmodel.com/download/COMPLETE $\% 20$ Morin $\% 20$ Arens $\% 20$ Marsh total Bi factor $\% 20$ ESEM Final.pdf (accessed 1-6-15)

Naffziger, D. W., Bott, J. P., and Mueller, C. B. (2010). Study Abroad: Validating the Factor Analysis of Student Choices. International Business: Research, Teaching and Practice, 4(1).

Nyaupane, G. P., Paris, C. M., and Teye, V. (2010) Study abroad motivations, destination selection and pre-trip attitude formation. International Journal of Tourism Research, 13(3), 205-217.

Powers, E. (2006). Intro to Study Abroad. Inside Higher Ed, July 28, available at http://www.insidehighered.com/news/2006/07/28/abroad (accessed 8-4-14)

Preston, K. (2012) The Impact of Studying Abroad on Recent College Graduates' Careers, May Available at http://www.iesabroad.org/study-abroad/why/career-benefits (accessed 8-4-14)

Rexeisen, R. Anderson, P. Lawton, L. and Hubbard, A. (Fall, 2008) Study Abroad and Intercultural Development: A Longitudinal Study. Frontiers: The Interdisciplinary Journal of Study Abroad,17, 1-20.

Ruhter McMillan, A., and Opem, G. (2004). Study abroad: A lifetime of benefits. Abroad View Magazine, 6(2), 58, 60-61.

Sanchez, C. M., Fornerino, M., and Zhang, M. (2006) Motivations and the Intent to Study Abroad Among U.S., French, and Chinese Students. Journal of Teaching in International Business, 18(1), 27 52.

Study Abroad 360. Top Ten Reasons to Study Abroad. available at http://www.studyabroad360.com/articles/top-ten-reasons-to-study-abroad (accessed 8-4-14)

StudyAbroad.com. Study Abroad Parent Guide: The Top Ten Reasons for Study Abroad. Available at http://www.studyabroad.com/guides/parentsguide/reasonstostudy.html (accessed 8-7-09)

Sumka, S. (1999). Educational Travel as a Model for Responsible Tourism: The Impact of Study Abroad. Transitions Abroad, May/June. Available at http://www.transitionsabroad.com/listings/study/articles/studymay1.shtml (accessed 8-4-14)

The Center for Global Education. Why Study Abroad. Available at http://www.globaled.us/now/whystudyabroadintro.html (accessed 8-4-14)

Vande Berg, M., Connor-Linton, J., and Paige, R.M. (2009) The Georgetown Consortium Project: Interventions for Students Living Abroad. Frontiers: The Interdisciplinary Journal of Study Abroad,18, $1-75$.

Vistawide. Why study abroad? 10 reasons why you should study in a foreign country. Available at http://www.vistawide.com/studyabroad/why study abroad.htm (accessed 8-4-14) 
Appendix 1: Exploratory Factor Analysis

\begin{tabular}{|c|c|c|c|c|c|}
\hline Variable & $\begin{array}{l}\text { World } \\
\text { Enlightenment }\end{array}$ & Entertainment & $\begin{array}{l}\text { Personal } \\
\text { Growth }\end{array}$ & $\begin{array}{l}\text { Career } \\
\text { Development }\end{array}$ & Communality \\
\hline Learn about the world & 0.829 & 0.028 & -0.207 & -0.028 & 0.732 \\
\hline $\begin{array}{l}\text { Better understand } \\
\text { different cultures }\end{array}$ & 0.791 & -0.021 & -0.165 & -0.157 & 0.678 \\
\hline $\begin{array}{l}\text { Interact with people from } \\
\text { other countries }\end{array}$ & 0.780 & 0.063 & -0.168 & -0.034 & 0.641 \\
\hline Expand my world view & 0.720 & 0.030 & -0.237 & -0.132 & 0.593 \\
\hline $\begin{array}{l}\text { Enhance my } \\
\text { understanding of global } \\
\text { affairs and events }\end{array}$ & 0.703 & -0.043 & -0.113 & -0.200 & 0.549 \\
\hline $\begin{array}{l}\text { Increase my } \\
\text { understanding of the } \\
\text { world }\end{array}$ & 0.681 & 0.102 & -0.257 & -0.255 & 0.605 \\
\hline $\begin{array}{l}\text { Become acquainted with } \\
\text { people different from me }\end{array}$ & 0.650 & 0.028 & -0.248 & -0.247 & 0.546 \\
\hline Go out drinking & -0.011 & -0.813 & -0.030 & 0.106 & 0.674 \\
\hline Do some serious partying & -0.025 & -0.801 & 0.045 & 0.112 & 0.656 \\
\hline $\begin{array}{l}\text { Make my friends a little } \\
\text { envious of me }\end{array}$ & -0.040 & -0.711 & 0.054 & -0.010 & 0.511 \\
\hline $\begin{array}{l}\text { Accumulate better stories } \\
\text { than my friends }\end{array}$ & -0.034 & -0.698 & -0.035 & -0.174 & 0.520 \\
\hline $\begin{array}{l}\text { Experience the local } \\
\text { nightlife (clubs, bars, etc.) }\end{array}$ & 0.103 & -0.676 & -0.192 & -0.101 & 0.515 \\
\hline Buy memorable souvenirs & 0.099 & -0.645 & -0.077 & -0.235 & 0.487 \\
\hline $\begin{array}{l}\text { Have a romantic } \\
\text { encounter }\end{array}$ & -0.137 & -0.645 & -0.063 & -0.025 & 0.440 \\
\hline $\begin{array}{l}\text { Learn to stand on my } \\
\text { own two feet }\end{array}$ & 0.318 & -0.118 & -0.764 & -0.052 & 0.701 \\
\hline $\begin{array}{l}\text { Increase my self- } \\
\text { confidence }\end{array}$ & 0.134 & -0.114 & -0.699 & -0.276 & 0.596 \\
\hline $\begin{array}{l}\text { Become more } \\
\text { independent }\end{array}$ & 0.298 & -0.094 & -0.691 & -0.218 & 0.623 \\
\hline Grow as a person & 0.358 & 0.073 & -0.617 & -0.004 & 0.515 \\
\hline Gain maturity & 0.370 & -0.093 & -0.610 & -0.004 & 0.518 \\
\hline Better understand myself & 0.423 & 0.001 & -0.539 & -0.123 & 0.579 \\
\hline $\begin{array}{l}\text { Enhance my employment } \\
\text { prospects }\end{array}$ & 0.114 & -0.159 & -0.174 & -0.825 & 0.749 \\
\hline Gain career skills & 0.216 & -0.039 & -0.172 & -0.821 & 0.751 \\
\hline Prepare for my career & 0.228 & -0.109 & -0.084 & -0.767 & 0.659 \\
\hline $\begin{array}{l}\text { Gain in-depth knowledge } \\
\text { in my chosen field }\end{array}$ & 0.327 & -0.062 & 0.012 & -0.745 & 0.666 \\
\hline Build my resume & 0.137 & -0.248 & -0.161 & -0.712 & 0.614 \\
\hline $\begin{array}{l}\text { Learn to handle new } \\
\text { circumstances }\end{array}$ & 0.700 & -0.016 & -0.436 & -0.038 & 0.681 \\
\hline $\begin{array}{l}\text { Develop cross-cultural } \\
\text { skills }\end{array}$ & 0.631 & 0.098 & -0.080 & -0.393 & 0.569 \\
\hline Broaden my horizons & 0.597 & 0.027 & -0.310 & -0.151 & 0.476 \\
\hline $\begin{array}{l}\text { Learn about historical } \\
\text { events }\end{array}$ & 0.591 & -0.084 & -0.038 & -0.063 & 0.362 \\
\hline $\begin{array}{l}\text { Learn about religions of } \\
\text { the world }\end{array}$ & 0.558 & -0.285 & -0.004 & 0.003 & 0.393 \\
\hline
\end{tabular}




\begin{tabular}{|c|c|c|c|c|c|}
\hline $\begin{array}{l}\text { Develop skills to face } \\
\text { challenging situations }\end{array}$ & 0.533 & -0.056 & -0.310 & -0.300 & 0.474 \\
\hline $\begin{array}{l}\text { Explore the arts (visit } \\
\text { museums, attend concerts } \\
\text { and cultural } \\
\text { performances, view } \\
\text { architecture, etc.) }\end{array}$ & 0.454 & -0.219 & -0.058 & -0.135 & 0.276 \\
\hline $\begin{array}{l}\text { Bring home items unique } \\
\text { to my host country }\end{array}$ & 0.223 & -0.581 & -0.075 & -0.179 & 0.426 \\
\hline $\begin{array}{l}\text { Take electives not } \\
\text { available at home }\end{array}$ & 0.047 & -0.456 & -0.082 & -0.279 & 0.295 \\
\hline $\begin{array}{l}\text { Explore my ethnic } \\
\text { background }\end{array}$ & 0.212 & -0.285 & -0.245 & -0.075 & 0.192 \\
\hline Re-invent myself & 0.068 & -0.376 & -0.504 & -0.209 & 0.444 \\
\hline $\begin{array}{l}\text { Escape from the boredom } \\
\text { of my routine }\end{array}$ & -0.021 & -0.469 & -0.427 & 0.019 & 0.403 \\
\hline Variance & 7.3460 & 4.8971 & 3.9377 & 3.9255 & 20.1063 \\
\hline$\%$ Variance & 0.199 & 0.132 & 0.106 & 0.106 & 0.543 \\
\hline
\end{tabular}

Note: The following 16 items were eliminated from the original set of 53 during the first round of factor analysis: Improve my intercultural communication skills; Have fun; Enjoy life; Have an adventure; Enhance my prestige; Eat new foods; See things I've only known from pictures; Escape from my personal problems; Improve my language skills; Fulfill a graduation requirement; Spend time and share experiences with friends from school; Learn how to cope with situations where I don't know what to do; Visit friends/relatives overseas; Accompany someone I know; Family members want me to go; Friends want me to go. 


\section{Appendix 2: The Motivation to Study Abroad (MSA)}

How important is each of the following in motivating you to participate in this study abroad program?

\begin{tabular}{|c|c|c|c|c|c|}
\hline & $\begin{array}{l}\text { Not at all } \\
\text { important }\end{array}$ & $\begin{array}{l}\text { Slightly } \\
\text { important }\end{array}$ & Important & $\begin{array}{l}\text { Very } \\
\text { important }\end{array}$ & $\begin{array}{l}\text { Absolutely } \\
\text { essential }\end{array}$ \\
\hline Gain maturity & 1 & 2 & 3 & 4 & 5 \\
\hline $\begin{array}{l}\text { Experience the local nightlife (clubs, bars, } \\
\text { etc.) }\end{array}$ & 1 & 2 & 3 & 4 & 5 \\
\hline Prepare for my career & 1 & 2 & 3 & 4 & 5 \\
\hline $\begin{array}{l}\text { Become acquainted with people different } \\
\text { from me }\end{array}$ & 1 & 2 & 3 & 4 & 5 \\
\hline Better understand myself & 1 & 2 & 3 & 4 & 5 \\
\hline Increase my self-confidence & 1 & 2 & 3 & 4 & 5 \\
\hline Enhance my employment prospects & 1 & 2 & 3 & 4 & 5 \\
\hline Increase my understanding of the world & 1 & 2 & 3 & 4 & 5 \\
\hline Gain career skills & 1 & 2 & 3 & 4 & 5 \\
\hline Have a romantic encounter & 1 & 2 & 3 & 4 & 5 \\
\hline Expand my world view & 1 & 2 & 3 & 4 & 5 \\
\hline Go out drinking & 1 & 2 & 3 & 4 & 5 \\
\hline Make my friends a little envious of me & 1 & 2 & 3 & 4 & 5 \\
\hline Grow as a person & 1 & 2 & 3 & 4 & 5 \\
\hline $\begin{array}{l}\text { Enhance my understanding of global affairs } \\
\text { and events }\end{array}$ & 1 & 2 & 3 & 4 & 5 \\
\hline Do some serious partying & 1 & 2 & 3 & 4 & 5 \\
\hline Gain in-depth knowledge in my chosen field & 1 & 2 & 3 & 4 & 5 \\
\hline Interact with people from other countries & 1 & 2 & 3 & 4 & 5 \\
\hline Build my resume & 1 & 2 & 3 & 4 & 5 \\
\hline Become more independent & 1 & 2 & 3 & 4 & 5 \\
\hline Better understand different cultures & 1 & 2 & 3 & 4 & 5 \\
\hline Learn to stand on my own two feet & 1 & 2 & 3 & 4 & 5 \\
\hline Learn about the world & 1 & 2 & 3 & 4 & 5 \\
\hline
\end{tabular}




\section{Appendix 3: Scoring the MSA:}

The MSA yields a set of four scores. Means should be computed for the items measuring each of the four dimensions, World Enlightenment, Personal Growth, Career Development, and Entertainment.

\begin{tabular}{|l|l|}
\hline \multicolumn{2}{|l|}{ World Enlightenment (7) } \\
\hline Item number & Statement \\
\hline $\mathbf{4}$ & Become acquainted with people different from me \\
\hline $\mathbf{8}$ & Increase my understanding of the world \\
\hline $\mathbf{1 1}$ & Expand my world view \\
\hline $\mathbf{1 5}$ & Enhance my understanding of global affairs and events \\
\hline $\mathbf{1 8}$ & Interact with people from other countries \\
\hline $\mathbf{2 1}$ & Better understand different cultures \\
\hline $\mathbf{2 3}$ & Learn about the world \\
\hline Personal Growth (6) \\
\hline $\mathbf{1}$ & Gain maturity \\
\hline $\mathbf{5}$ & Better understand myself \\
\hline $\mathbf{6}$ & Increase my self-confidence \\
\hline $\mathbf{1 4}$ & Grow as a person \\
\hline $\mathbf{2 0}$ & Become more independent \\
\hline $\mathbf{2 2}$ & Learn to stand on my own two feet \\
\hline Career Development (5) \\
\hline $\mathbf{3}$ & Prepare for my career \\
\hline $\mathbf{7}$ & Enhance my employment prospects \\
\hline $\mathbf{9}$ & Gain career skills \\
\hline $\mathbf{1 7}$ & Gain in-depth knowledge in my chosen field \\
\hline $\mathbf{1 9}$ & Build my resume \\
\hline \multicolumn{2}{|l|}{} \\
\hline Entertainment (5) \\
\hline $\mathbf{2}$ & Experience the local nightlife (clubs, bars, etc.) \\
\hline $\mathbf{1 0}$ & Have a romantic encounter \\
\hline $\mathbf{1 2}$ & Go out drinking \\
\hline $\mathbf{1 3}$ & Make my friends a little envious of me \\
\hline $\mathbf{1 6}$ & Do some serious partying \\
\hline & \\
\hline
\end{tabular}

